\title{
Uterine luminal proteins of mice
}

\author{
R. E. Gore-Langton and M. A. H. Surani \\ Physiological Laboratory, Cambridge CB2 3EG, U.K.
}

Hormone-dependent changes in the proteins of uterine secretions are thought to be involved in the control of embryo metabolism and implantation (McLaren, 1973; Surani, 1975a). Blastocysts show metabolic and proliferative depression during delayed implantation (Weitlauf, 1974; Sherman \& Barlow, 1972), whereas implanting embryos have greatly increased activities (McLaren, 1973). Previous hypotheses suggested that these embryonic responses are regulated by uterine factors having unique or limited specific functions (Psychoyos \& Bitton-Casimiri, 1969; Mintz, 1971). A new concept is developing in which embryonic activities may be co-ordinately and reversibly influenced by adaptation of the embryo to the total intraluminal environment (Surani, 1975a; Webb \& Surani, 1975). Rat uterine secretions show oestrogen-dependent changes in high molecular weight proteins which suggest that these proteins may be particularly important components of the environmental effect (Surani, 1975a). The profiles of proteins in the mouse uterine lumen have been studied for changes which could regulate embryo activities according to these hypotheses.

Randomly bred CFLP mice (Carworth, Europe) between 6 and 10 weeks of age were maintained on a lighting schedule of 05.00 to 19.30 hours. In these mice blastocyst attachment for implantation begins late on Day 4 and continues into Day 5 (Day $1=$ day of finding a vaginal plug). Mice with vaginal plugs were chosen from females placed overnight with fertile or vasectomized males and thus presumed to be pregnant or pseudopregnant, respectively. Ovaries were examined during dissection and the possession of fresh CL was used as a further criterion for pregnancy or pseudopregnancy. Some pseudopregnant or pregnant mice were induced to superovulate before mating by i.p. injection of 10 i.u. PMSG (Folligon: Intervet) between 12.00 and 14.00 hours followed $48 \mathrm{hr}$ later by 10 i.u. HCG (Chorulon: Intervet).

Uterine flushings were collected between 10.00 and 14.00 hours from two or three animals for separate analyses on each of the first 6 days of pregnancy or pseudopregnancy and the series were repeated independently. The method of flushing was that of Surani (1975a), except that $0 \cdot 1 \mathrm{ml}$ sample buffer was used to flush each uterine horn. Serum samples for comparison were prepared by adding $2 \mu \mathrm{l}$ freshly collected serum to $0.2 \mathrm{ml}$ sample buffer and treated in the same way as the uterine flushings. Histological sections of the uterus were examined to confirm that the epithelium remained intact after flushing. Sample buffer containing sodium dodecyl sulphate (SDS) and $\beta$-mercaptoethanol, and the separation of proteins on $7.5 \%$ polyacrylamide gels at $\mathrm{pH} 7 \cdot 2$, were identical to previous procedures (Surani, 1975a). Separation occurs on the basis of molecular weight. Protein bands were stained with Coomassie Brilliant Blue and densitometric scans were prepared on a Chromoscan (Joyce-Loebl Ltd) with complementary filter. Areas under the densitometry peaks provided an estimate of the relative concentrations of particular protein bands.

A highly variable component of low molecular weight occurred in the flushings of uteri of all physiological states (Text-figs 1 and 2, first peak from right). This prominent component may be of serum origin since a similar band is seen in mouse serum. However, direct serum contamination during flushings is less likely than serum contribution by transudation which might favour the entrance of low molecular weight molecules.

Typical protein changes observed during the first 6 days of normal pregnancy are shown in Text-fig. 1. Characteristic changes in individual protein bands were not normally apparent, possibly due to considerable variation between animals, but there was a trend towards a relative increase in the concentrations of higher molecular weight proteins on Days 3 to 5 . These increasing proteins included what was apparently albumin as well as numerous larger macromolecules $\left(>10^{5} \mathrm{~mol}\right.$. wt). It was not possible to distinguish if any entirely new proteins appeared in this high molecular weight region. By Day 6 these higher molecular weight proteins had usually returned to levels similar to 
those found before Day 3. An increase in the total luminal protein content was also apparent from Day 4 onwards. However, the area under the densitometry curve was not a reliable measure of total luminal protein due to the occasional incomplete recovery of sample buffer from flushed uterine horns. Similar trends were found in samples from pseudopregnant females, suggesting that embryos do not detectably alter uterine luminal protein profiles in these circumstances.

The effects of superovulation on changes in uterine luminal proteins (Text-fig. 2) were examined during pseudopregnancy in case gonadotrophin treatment also influenced any embryonic contribution to the luminal proteins. There were no obvious qualitative differences in the flushings from superovulating pseudopregnant and superovulating pregnant mice before luminal closure on Day 5 . However, superovulation appeared to increase the luminal protein content on Day 6 of pregnancy compared with pseudopregnancy (see Text-fig. 2).

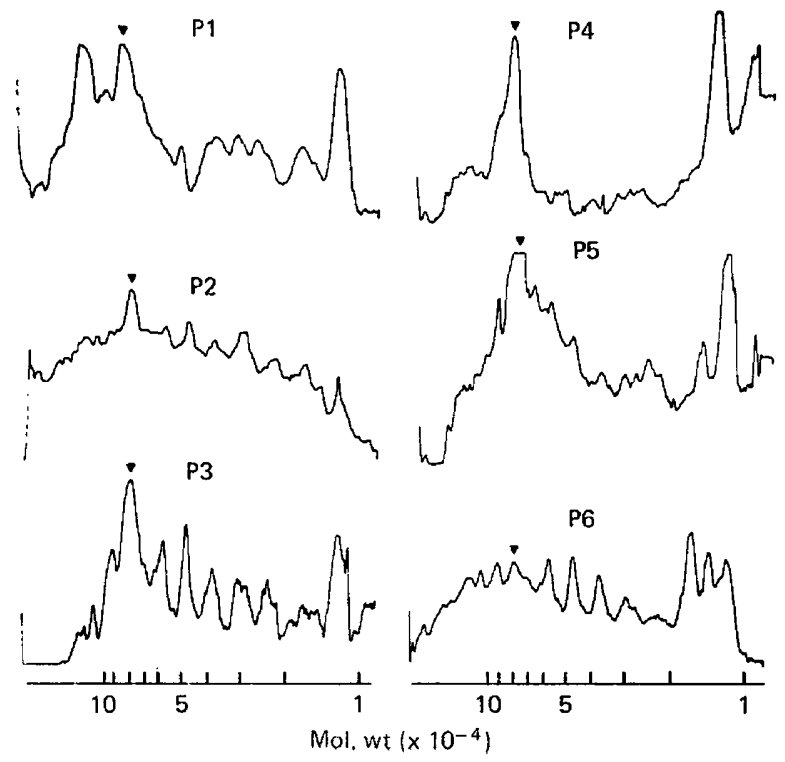

Text-fig. 1. The protein profiles of the uterine flushings of pregnant mice, Days 1 to 6 . The position of serum albumin is indicated $(\nabla)$. The molecular weight scale was estimated from a calibration curve of reference proteins.

The hormone treatment of the pseudopregnant mice enhanced the definition of many proteins occurring in pregnancy, but there were no apparent qualitative differences. On Day 1, some low molecular weight components $\left(<2 \times 10^{4} \mathrm{~mol}\right.$. wt) were usually the largest individual peaks, their relative concentration declining thereafter, and the levels of the high molecular weight proteins $\left(>10^{5} \mathrm{~mol}\right.$. wt) that became characteristic of Day 4 and later flushings were low. Other striking characteristic changes following superovulation were the shift in the relative quantities of the components in each of two protein pairs on either side of the albumin peak (Text-fig. 2, Pairs 1 and 2). Estimated molecular weights for one pair were 8.2 and $8.0 \times 10^{4}$ and for the other pair were 5.1 and $5.5 \times 10^{4}$. In Pair 1, the larger molecular weight component predominated on Days 1 and 2 , the relative peak heights became almost equal on Day 3, and during Days 4 to 6 the smaller weight component predominated. A very similar sequence occurred with Pair 2, except that it was the smaller molecular weight component which first predominated slightly and the larger component doing so by Day 4 . The protein pairs ( 1 and 2 ) were seen during normal pregnancy, especially Day 3 (Text-fig. 1). Gonadotrophin treatment presumably stimulates ovarian oestrogen production which in turn results in an increased and possibly better synchronized protein secretion into the lumen. The small amounts of these proteins in pregnancy secretions does not reduce their possible significance as specific regulators involved in implantation. They may be invelved in the control of embryonic 
metabolism or they may have a specialized function in zona lysis (Mintz, 1971; Surani, 1975b) or cell surface modification (Pinsker \& Mintz, 1973).

Our observations on the uterine intraluminal environment in the mouse suggest an oestrogencontrolled sequence of protein changes which coincides with the time of implantation. These changes include an increased presence of higher molecular weight proteins of which many may be derived from serum. Changes in a small number of apparently uterine-specific secretions also occur. The specific changes in uterine secretion proteins, readily detectable on Day 3 and 4 of pseudopregnancy after superovulation, may provide distinctive markers of the uterine epithelial differentiation which is shown by the maximal proliferation of the glandular and luminal epithelia on Day 3 of pregnancy (Finn, 1974). Rising progesterone levels during the luteal phase cause cessation of epithelial mitotic activity by Day 4 and epithelial cell differentiation proceeds in readiness for blastocyst attachment.

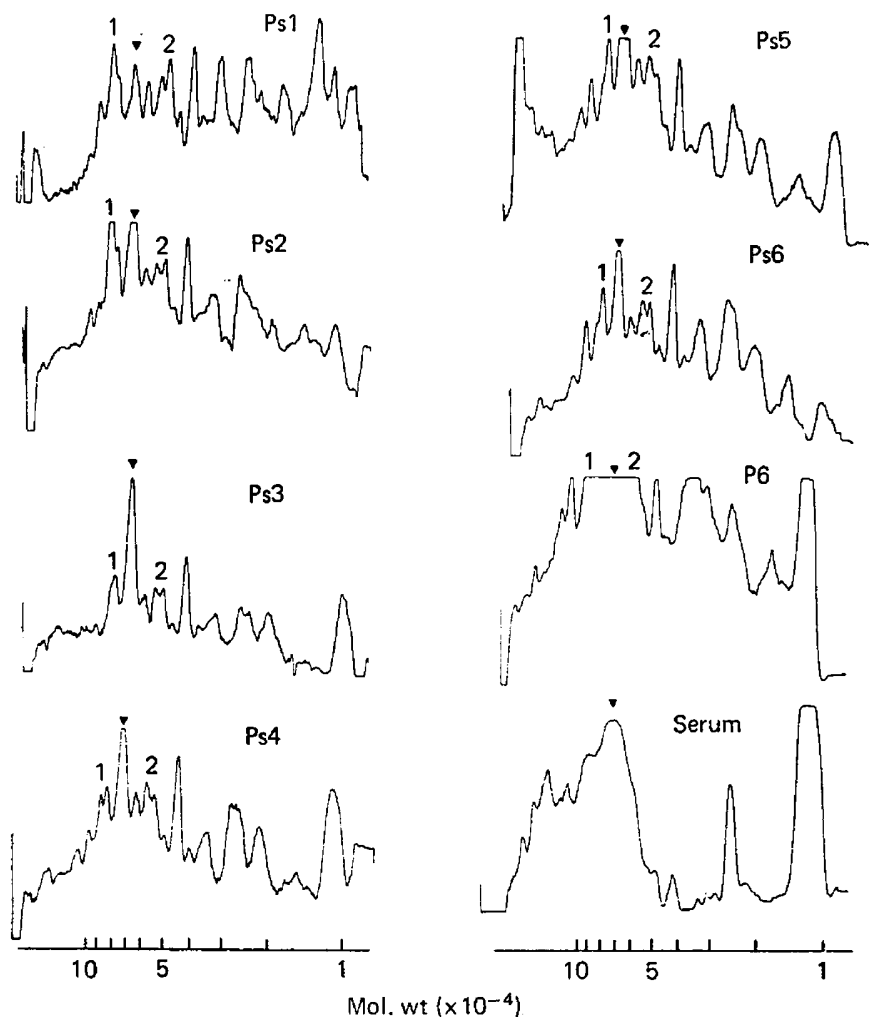

Text-fig. 2. The effect of superovulation on the protein profiles of the uterine flushings from pseudopregnant (Ps1-Ps6) and pregnant (P6) mice. Mouse serum is shown for comparison. The position of serum albumin is indicated $(\boldsymbol{V})$ and the protein pairs referred to in the text are numbered 1 and 2 . The molecular weight scale was estimated from a calibration curve of reference proteins.

Although the secretion by the uterus of non-proteins (Aitken, 1974) could also influence embryos, the observed changes in uterine intraluminal proteins suggest a probable means by which the regulation of embryonic activities at implantation may be accomplished. The high molecular weight proteins may modulate embryonic metabolism and proliferation as previously postulated (Surani, 1975a, b). This type of control is believed to be similar to that which occurs in various eukaryotic cells showing a so-called pleiotypic response to serum starvation (Hershko, Mamont, Shields \& Tomkins, 1971; Pardee, 1974). This type of response is generally characterized by a co-ordinated control of metabolism in which reversible enhancement can be caused by a number of substances. Considerable lability in the metabolic response of embryos has already been demon- 
strated by reciprocal transfers of implanting and implanted blastocysts (Weitlauf, 1974; Psychoyos, 1961).

We thank Professor C. R. Austin, Dr R. G. Edwards and Dr F. T. G. Webb. Financial support from the Ford Foundation, a Queen Elizabeth II British Columbia Centennial Scholarship (R.E.G.L.) and the Medical Research Council (M.A.H.S) is gratefully acknowledged.

\section{References}

Aitken, R.J. (1974) Calcium and zinc in the endometrium and uterine flushings of the roe deer (Capreolus capreolus) during delayed implantation. J. Reprod. Fert. 40, 333-340.

FinN, C.A. (1974) Recent research on implantation in animals. Proc. $R$. Soc. Med. 67, 927-932.

Hershko, A., Mamont, P., Shields, R. \& Tomkins, G.M. (1971) Pleiotypic response. Nature, New Biol. 232, 206-211.

MCLAREN, A. (1973) Blastocyst activation. In Regulation of Mammalian Reproduction, pp. 321-328. Eds S. J. Segal, R. Crozier, P. A. Corfman \& P. G. Condliffe. Thomas, Springfield, Illinois.

MiNTz, B. (1971) Control of embryo implantation and survival. Adv. Biosci. 6, 317-340.

PARDEe, A.B. (1974) A restriction point for control of normal animal cell proliferation. Proc. natn. Acad. Sci. U.S.A. 71, 1286-1290.

Pinsker, M.C. \& Mintz, B. (1973) Changes in cell surface glycoproteins of mouse embryos before implantation. Proc. natn. Acad. Sci. U.S.A. 70, 1645-1648.

Psychoyos, A. (1961) Nouvelles recherches sur l'ovoimplantation. C. $r$ hebd. Séanc. Acad. Sci., Paris 252, 2306-2311.
Psychoyos, A. \& Bitton-CasimiRt, V. (1969) Caption in vitro d'un precurseur d'acide ribonucleique (ARN) (uridine-5- ${ }^{3} \mathrm{H}$ ) par le blastocyste du rat: differénce entre blastocyste normaux et blastocyste en diapause. C. r. hebd. Séanc. Acad. Sci., Paris 268, 188-192.

Sherman, M.I. \& Barlow, P.W. (1972) Deoxyribonucleic acid content in delayed mouse blastocyst. J. Reprod. Fert. 29, 123-126.

SURANI, M.A.H. (1975a) Hormonal regulation of proteins in the uterine secretion of ovariectomized rats and the implications for implantation and embryonic diapause. J. Reprod. Fert. 43, 411417.

SURANI, M.A.H. (1975b) Zona pellucida denudation, blastocyst proliferation and attachment in the rat. J. Embryol. exp. Morph. 33, 343-353.

Webb, F.T.G. \& Surani, M.A.H. (1975) Influence of environment on blastocyst proliferation, differentiation and implantation. In Regulation of Growth and Differentiated Function in Eukaryotic Cells, pp. 519522. Ed. G. P. Talwar. Raven Press, New York.

Weitlauf, H.M. (1974) Metabolic changes in the blastocysts of mice and rats during delayed implantation. J. Reprod. Fert. 39, 213-224.

Received 9 July 1975 